\title{
Corporate Finance in the Law School Curriculum
}

Corporation Finance: Cases and Materials. By Robert W. Hamilton: West Publishing Co., St. Paul, Minnesota, 1984.

pp. xxiii, 895. \$27.95.

\section{Reviewed by William W. Bratton, Jr.*}

In contemporary corporate law pedagogy, "Corporate Finance" denotes an advanced corporate course combining conventional legal materials on finance witli materials on practical and theoretical finance economics. This was a novel curricular concept when Professors Victor Brudney and Marvin A. Chirelstem brought out the first edition of their Corporate Finance casebook in 1973.1 Times have changed. Such mixes of law and economics liave become routine, ${ }^{2}$ and Corporate Finance has joined the establishinent of generally offered upper-class law school courses. ${ }^{3}$ Law students associate Corporate Finance with Securities Regulation as a portal to corporate practice. ${ }^{4}$ The second edition of the Brudney and Chirelstein casebook, brought out in 1979, has entered middle age. And witl the recent publication of Professor Robert W. Hamil-

* Associate Professor of Law, Benjamin N. Cardozo School of Law, Yeshiva University. A.B. 1973, J.D. 1976, Columbia University. Thanks to Chuck Yablon and Paul Shupack for helpful comnents.

1. V. BRudNey \& M. Chirelstein, Cases AND MATERIALs on Corporate Finance (1st ed. 1972). The book is in its second edition. See V. BrudNeY \& M. ChIRELsteIn, Cases AND MATERIALS ON CORPORATE FINANCE (2d ed. 1979) [heremafter cited as BRUDNEY \& CHIRELSTEIN, CORPORATE FINANCE].

2. See, eg., J. Cox, Financial INFormation, Accounting and the Law: Cases and MATERIALS 145-89 (1980) (takes care to present valuation and the efficient nuarket hypothesis); $R$. POSNER \& K. SCOTT, ECONOMICS OF CORPORATION LAW AND SECURITIES REgulATION (1980) (text for a course devoted to corporate law and economics); L. Solomon, R. STEvenSON, \& D. Schwartz, Corporations, Law and Policies: Materials and Problems 68-92 (1982) (contains an excellent iutroduction to valuation); id. at 94-96, 132-34, 865-72 (includes the "Chicago school" point of view on a nuniber of issues); see also R. Pozen, Financial InStitutions: CaSes Materials aNd Problems on INVESTMENT MANAGement (1978); D. RATNER, INSTITUTIONAL INVESTORS: TEACHING Materials (1978).

3. Two hundred twenty-one full-time law teachers listed it on their resumes in Association OF AMERICAN LAw SChOOLS, DIREcTORY OF LAw TEACHers (1983). One hundred thirty-four of this group were listed as current teachers of the course during the 1983-84 school year. The total is sinaller than the total listed in the Directory under "Corporate Finance" because the heading includes a number of business courses other than Corporate Finance, among then Business Planning and Corporate Reorganizations. The Directory lists two hundred twenty-five teachers of Securities Regulation.

4. Oddly, some of those students convinced that the course is essential to their career preparation will be going to work for corporate practitioners who have no idea that the course exists. 
ton's Corporation Finance, ${ }^{5}$ the hittle community of corporate finance instructors even has a choice of casebooks.

This review essay takes the occasion of the publication of Hamilton's book to comment on the concept of the Corporate Finance course that shapes both books. The essay first looks at the course Brudney and Chirelstein introduced, explicating their accoinphishment. ${ }^{6}$ Then it explores the Hamilton alternative. ${ }^{7}$ Finally, it notes and questions the lin1its of the curricular concept and suggests soine expansions. ${ }^{8}$

\section{The Curricular Concept}

A traditional set of corporate finance teaching niaterials is available in the back pages of the Cary Corporations casebook. ${ }^{9}$ One doubts that these pages are widely read; they were gathering dust when the Brudney and Chirelstein book came along in 1973. Postwar growth in the quantity of law governing shareholder/nnanageınent relationships had squeezed thein out of the four-hour Corporations syllabus. ${ }^{10}$ With proxy rules, majority shareholder duties, and insider trading prohibitions to be dealt with, little time remamed for inergers and acquisitions, and even less for senior securities, legal capital, dividend regulation, and recapitalizations. Brudney and Chirelstein solved this timing problein by removing the finance inaterials into a new "advanced corporations" format.

Their book also addressed a inore substantial problem. In 1973, corporate law teaching inaterials did not promote discourse on a particularly coinpelling level. ${ }^{11}$ Merely bifurcatimg the Corporations course would have done little to enliven or enrich things. Fortunately, finance economics stood ready to facilitate an advance in the level of discussion in much the same way price economics already had advanced the discussion in the antitrnst area. Brudney and Chirelstein recognized this and integrated the subject inatter at the back of the Cary casebook with the basic points inade by an introductory finance text. These inaterials have

5. R. Hamilton, Corporation Finance: Cases and Materials (1984).

6. See infra notes 9-37 and accompanying text.

7. See infra notes $38-47$ and accompanying text.

8. See infra notes $48-87$ and accompanying text.

9. See W. CARY \& M. Eisenberg, Cases and Materials on Corporations 1015-639 (5th ed. unabr. 1980).

10. We see this phenomenon by comparing the third and fourth editions of the Cary text. The third edition, published in 1959, wraps up fiduciary duty and insider trading by page 626 and derivative suits by page 753. R. Baker \& W. CARY, CASES and Materials on Corporations (3d ed. 1959). The corresponding pages in the fourth edition are 867 and 1029. W. CARY, CASES AND MATERIALS ON CORPORATIONS (4th ed. 1969).

11. See Chisum, Book Review, 86 HARv. L. Rev. 1103, 1103-04 (1973) (review of the first edition of the Brudney \& Chirelstem casebook in which the author notes that few law students were inspired to go beyond the basic corporations course). 
a natural affinity: The integrated unit erases the ineinory of the rationale behind the old regime of separate pedagogy.

Corporate Finance is a casebook in the grand style, one of the rare "thenie" casebooks that brings its collection of materials inside an overarching evaluative framework. ${ }^{12}$ The organizational touchstone is the goal of value maximization. The book takes the value-inaximizing decision, breaks it into its coinponent parts, and then displays it $m$ operation in various investnient and financial contexts. Legal and business contexts are included and courts and administrative agencies are juxtaposed with corporate managers, investors, and portfoho managers in the role of value-maximizing decisionmakers.

The first part of the book is a treatınent of valuation and illustrates this heuristic technique. It offers a step-by-step exposition of valuation in the manner of an introductory finance textbook, starting with discounting and coinpounding and buildnig to risk and return. ${ }^{13}$ This introduction to the analytical tools utilized in busniess decisionmaking is sandwiched between two vintage exainples of valuation in legal decisionniaking. One is an SEC advisory report in a corporate reorganization proceeding ${ }^{14}$ and the other is an appellate opinion in a Delaware merger appraisal proceeding. ${ }^{15}$ Complex valuations directly determine legal rights in both cases. The juxtaposed business and legal materials invite a inultifaceted Socratic exercise. The business inaterials show the student that business practice determines values. From there it follows that to the extent it seeks to approximate real-world economic results, legal valuation must be informed by business practice. This conclusion prompts a critique of the legal materials: The students apply their knowledge of the business mechanics agamst old legal valuation standards not consistent with business practice. By the conclusion of the exercise, they have constructed for themselves the revised approach to valuation currently operative in "advanced" legal opinion. ${ }^{16}$ In the process, any lines in the students' minds separating corporate legal pohicy and economic reality have disappeared.

12. Another such rarity is H. HaRT \& H. WeChSLER, THE Federal CourTs AND the FedERAL SYSTEM (1953), which introduced the now orthodox Federal Courts course.

13. BRUdNEY \& Chirelstein, CoRporate FinanCE, supra note 1, at 35-78.

14. Id. at 6-30 (excerpting In re Atlas Pipeline Corp., 9 S.E.C. 416 (1941)).

15. Id. at 70-73, 567-78 (excerpting Francis I. Du Pont \& Co. v. Universal City Studios, Inc., 312 A.2d 344 (Del. Ch. 1973), aff'd, 334 A.2d 216 (Del. 1975)).

16. See, eg., Weinberger v. UOP, Inc., 457 A.2d 701, 712-13 (Del. 1983) (repudiating the Delaware block approach to valuation "to the extent it excludes other generally accepted techniques used in the financial comınunity"); N.Y. BUS. CoRP. LAw § 623(h)(4) (McKinney Supp. 1983) ("fair value" of shares in appraisal proceeding to be determined in accordance with "the concepts and inethods then custoniary in the relevant securities and financial inarkets"). 
These materials pose basic questions on another level. They illustrate the difficulties that result when legal decisionmakers make investment and financing decisions while simultaneously balancing competing economic interests within a normative framework. The student gets the message that one party's value maximizing decisions soinetimes come at the expense of other parties with equally legitimate interests in the enterprise. And the student begins to appreciate that perfectly fair results are elusive when corporate pie-shicing contests are fought in legal arenas.

The main body of the book contains a succession of corporate and securities law topics, each offered as an exercise in understanding the interrelations of the law and value-maximizing decisionmaking. Thus, the student is introduced to contract and corporate law of long-term debt and preferred stock, ${ }^{17}$ and to statutes and cases regulating capital structure, ${ }^{18}$ dividends, ${ }^{19}$ and mergers and other corporate combinations. ${ }^{20}$ Then the student is introduced to federal regulation of the flow of information in securities markets, particularly security registration requirements and insider trading prohibitions. ${ }^{21}$ Finance theory complicates the picture frequently. 22

Brudney and Chirelstein enrich the discussion further by drawing on doctrimal materials from outside the traditional corporate and securities law categories. They round out their picture of corporate debtorcreditor relationships with materials on bankruptcy reorganization. ${ }^{23}$ In building a picture of the regulation of capital structure they draw on the "regulated industries," in particular, materials on regulation of public utilities and banks. ${ }^{24}$ This doctrinal outreach contributes to the valuation theme by illustrating the behavior of legal decisionmakers vested with primary investment and financial decisionmaking authority. Corporate law materials, molded by the business judgment tradition and a narrower set of policy concerns, camiot provide such illustrations.

17. BRUdNey \& ChiRELSTEIN, CORPORATE FinANCE, supra note 1, at 79-262.

18. Id. at 263-415.

19. Id. at $416-501$.

20. Id. at $502-772$.

21. Id. at 773-1235.

22. For example, consideration of the regulation of capital structure is enlivened by an exposition of the Modigliani-Miller proposition that capital structure is irrelevant to firm value. Id. at 387 . 409, 438-42. Similarly, materials on the regulation of the securities markets and market professionals are followed by portfolio theory and the efficient markets hypothesis, the theorists' explications of the effect of value-maximizing behavior in the context of competitive securities markets. Id. at 1143 93.

23. Id. at $123-70$.

24. Id. at $331=80$. 
The Brudney and Chirelstein book wears well. It provides good service to each of its three constituencies: academically oriented law students, career-oriented law students, and legal educators.

The book rewards the efforts of students inhabited by the spirit of normative inquiry with a better understanding of the costs and benefits of business regulation. Brudney and Chirelstein convey a sense of their scholarly interests to these students even while acting in the limited role of editors and occasional commentators. ${ }^{25}$ Their scholarship combines technical command of corporate law and business practice with sophisticated normative jurisprudence in the contemporary "fairness versus efficiency" mold. They break down and rebuild the legal literature's oversimiplified models of business reality and offer revised models more cognizant of real world complexities. Then they work fairness-versusefficiency conflicts through these models witl sensitivity to both economic and jurisprudential nuances. Their casebook asks students to perform similar analytical exercises on a smaller scale. Its overlay of practical and theoretical economics provides ground for a critique of the crude visions of reahty operative in the legal materials, and the legal materials give rise to successive fairness-versus-efficiency discussions.

Brudney and Chirelstein often display an anti-managerial moral and political disposition in their scholarship. When working in this mode they often prove willing to abandon the tailored jurisprudence of standards for less well-fitting but more easily applied rules. ${ }^{26}$ Fortunately, they keep this anti-managerialism well into the background in their casebook. Nothing inhibits participation by students with management-

25. Here "Brudney and Chirelstein" are referred to collectively, working both in collaboration and separately. The remarks in the text stem from my experience with, inter alia, Brudney \& Chirelstein, $A$ Restatement of Corporate Freezeouts, 87 YALE L.J. 1354 (1978) [heremafter cited as Brudney \& Chirelstein, Freezeouts], Brudney \& Chirelstein, Fair Shares in Corporate Mergers and Takeovers, 88 HARV. L. REV. 297 (1974) [heremafter cited as Brudney \& Chirelstein, Fair Shares], Brudney, Equal Treatment of Shareholders in Corporate Distributions and Reorganizations, 71 CALIF. L. REV. 1072 (1983) [heremafter cited as Brudney, Equal Treatment], Brudney, Dividends, Discretion, and Disclosure, 66 VA. L. REV. 85 (1980) [hereinafter cited as Brudney, Dividends], and Chirelstein, Towards a Federal Fiduciary Standards Act, 30 CLEv. ST. L. REv. 203 (1981).

26. See, e.g., Brudney \& Chirelstein, Freezeouts, supra note 25, at 1365 (suggesting that all "going private" transactions be prohibited); Brudney \& Chirelstem, Fair Shares, supra note 25, at 313-25 (suggesting that gains resulting from mergers of subsidiaries into parent corporations be divided equally between parent and the subsidiary as a percentage of premerger values); Brudney, Dividends, supra note 25, at 129 (impossibility of regulating management dividend decisions leads to recoinmendation of requirement of disclosure of reasons behind dividend deeisions); Brudney \& Clark, A New Look at Corporate Opportunities, 94 HARv. L. REv. 997, 1022-42 (1981) (recommending categorical prohibition of full-time executives of public corporations froun taking any other active business opportunities); Chirelstem, supra note 25, at 205-17 (recommending abandonment of common law fiduciary duty and fairness standards restricting managers in favor of legislated rules or standards of a more specific character). 
protective dispositions when the time comes to propose norms in Corporate Fimance class.

Next we consider the corps of career-oriented law students taking Corporate Finance as they mark time on the way to corporate practice in large law firms. Few of these students care that interdisciplinary study holds out opportunities for enriched discourse on law and policy. But the Brudney and Chirelstein concept of the course appeals to them nevertheless. They sense that its economic dimension contributes to their training as practitioners.

In fact, economic theory does bear on the corporate practice in which these students eventually will engage, even though such practice will draw few into full-fledged business decisionmaking. Those employed m large legal mstitutions will be drafting debt contracts, representing 10b-5 defendants, closing leveraged lease deals, packaging tax shelters and fighting legal battles for corporate control. The economic inaterials in the Brudney and Chirelstem book introduce them to the sources of value in these transactions. Exposure to the materials will enhance their understanding of the economic decisionmaking process of which their legal work will be a component. It will also enhance their understanding of the actions and inotivations of their future chents. Thus, the students should emerge better able to design and supervise valuable transactions for their chents. ${ }^{27}$ They will be rewarded for their diligence in Corporate Finance with a inarginal increase im professional effectiveness.

The Brudney and Chirelstem course may perform an additional professional function. Corporate lawyers have complicated relationships with their clients-the managers of business corporations. The lawyers want to provide management witl satisfactory service at the highest possible price. They also strive for professional autonomy ${ }^{28}$ and a residuum of control over managerial conduct. ${ }^{29}$ These aims tend to be inconsis-

27. For a transaction cost justification of corporate lawyering, see Gilson, Value Creation by Business Lawyers: Legal Skills and Asset Pricing, 94 YALE L.J. 239 (1984).

28. Complete autonomy is never achieved, of course. Although not yet a regulated industry, the legal profession is far from accountable only to itself. See G. HAZARD, Ethics in THE PRACTICE OF LAW xiv-xv, 15-19 (1978) (lawyers are constrained by their duties to, and dependence on, legal educators, employers, insurers, the organized bar, and the public at large).

29. One of corporate law's functions-and perhaps its most important function-is to facilitate control of the power corporate managers wield in society. See generally Frug, The Ideology of Bureaucracy in American Law, 97 HARV. L. REV. 1276 (1984) (arguing that corporate and administrative law, as defenders of the wielders of bureaucratic power, are actually deceptions which mask the nondenocratic nature of bureaucratic power). As the keeper of corporate law, in legislatures, courts, government agencies, and law offices, the legal profession wields this power against managers. Private practitioners share in this exercise even while acting as management attorneys when giving advice or giving (or withholding) opimons. Despite the awkwardness of their position, one detects no movement among corporate practitioners toward abandonment of the power they exercise in their relationships with their chents. 
tent. As a result, the legal profession has difficulty inaintaining friendly relationships with managers and simultaneously satisfying all of its professional aims. Widespread inclusion of elementary finance in the law school curriculum signifies a slight retreat in the legal profession's claim to autonomous power over business. The legal profession wields less power to the extent it disables itself froin imposing its uninformed intuitions. By teaching itself finance it admits that sensitivity to the constraints on the business profession may be necessary when lawyers formulate legal norms. But the retreat is only strategic. By informing itself, the legal profession gains authority when it seeks to impose its will on unwilling business persons. Furthermore, knowledge of elementary finance gives corporate practitioners an expanded base of shared intellectual experience with their professionally-educated business employers. If soine increased sense of solidarity between attorney and business chent results, the lawyers emerge with a better foundation upon which to work their balancing act.

In any event, successful innovations in legal pedagogy tend to becoine self-justifying to professionally-oriented students (and educators). A process of intellectual assimilation between law school and law office may occur, turning what at first seemed a purely academic project into an essential for practical lawyermg. ${ }^{30}$ In the case of the Brudney and Chirelstem Corporate Finance course, the process might work as follows: in 1973 an innovative casebook designed to deepen the student's understanding of the law by presenting the doctrime in its wider context appears. Students of the book carry their deepened understanding and the economic ideas behind it with thein into practice. Ideas from the casebook start to find their way into hitigators' briefs. Finally, the ideas begin to appear in the case law. Eventually a utilitarian corner is turned and the ideas go into the grab bag of notions and rhetorical devices routinely utilized in arguing and deciding cases. They become stock in the corporate lawyer's trade, and what was once academic theory is now another part of "real world" practitioner training.

The Brudney and Chirelstein course may already have reached an advanced stage $\mathrm{m}$ this process of assimilation. Hamilton notes that the efficient inarkets notion (one of the theoretical goods purveyed by Brudney and Chirelstein) has been important in a number of well-known opinions. ${ }^{31}$

30. The Federal Courts course, invented only in 1953, comes to mind. See supra note 12.

31. R. HAMILTON, supra note 5, at 209 n.8; see also Gilson \& Kraakman, The Mechanisms of Market Efficiency, 70 VA. L. REV. 549, 549-50 (1984) (discussing the broad acceptance by the legal community of the efficient capital markets theory). 
Finally, we consider the influence of the Corporate Finance course on the scholarly developinent of the Corporate Finance instructor. The precise role the Brudney and Chirelstein book has played in nurturing scholarship is difficult to ascertam. ${ }^{32}$ Although significant academic work employed economic theory to critique corporate law before the book's appearance in 1973,33 the quantity of such work has increased significantly smce then. Of course, many variables figure into the etiology of this growth. Not the least among these is the growth of interest among legal academics in the study of ideas froin other fields. ${ }^{34}$ But widespread adoption of the Brudney and Chirelstein book must be counted ainong these variables as well. Much scholarly enterprise has its genesis im problems discovered and inadequately resolved im teaching. ${ }^{35}$ Ties to the Corporate Finance course can be detected in and around inuch recent work on financial topics. ${ }^{36}$

Let us also consider a hypothetical legal educator who does not teach the Corporate Finance course but who concerns himself with the overall position of the law school in the educational and professional

32. The necessary survey of Corporate Finance instructors has not been undertaken in connection with the preparation of this essay. Causal einpiricism has been employed. See infra note 36 and accoinpanying text.

33. See, e.g., Manne, Mergers and the Market for Corporate Control, 73 J. Pol. EcoN. 110 (1965) (discussion of economic aspects of mergers); Wu, An Economist Looks at Section 16 of the Securities Exchange Act of 1934, 68 CoLUM. L. REV. 260 (1968) (discussion of economic issues related to insider tradimg).

34. Such interest has becoine particularly keen in the corporate area as prominent economists have taken up the study of corporate legal structure. See sources cited infra note 83.

35. Scholarly enterprise also can inake the teacher's grasp of what he teaches more secure. For discussion of the interrelationship of teaching and scholarship, see Kronman, Foreword: Legal Scholarship and Moral Education, 90 YALE L.J. 955 (1981).

36. The hiterature on subjects such as tender offers, sales of corporate control, and insider trading does not yield good exemplars for this point. Although these subjects are covered in the Corporate Finance course, they figure too prominently in the everyday aeademic discourse on corporate law for a given course or casebook to have had a visible influence.

The less heavily traversed fields of valuation, serrior securities, capital structure, and dividends are central to the Corporate Finance course and, as such, provide a better proving ground. Here we have work by a number of Corporate Finance instructors. On dividends, see Brudney, Dividends, supra note 25 (arguing, using economic as well as legal sources, that disclosure by management of the rcasons for dividend policy will correct stock prices), and Fischel, The Law and Economics of Dividend Policy, 67 VA. L. REV. 699 (1981) (arguing, in criticisın of Brudney, that broad discretion on management's part in determining dividend policy is preferable (also relying on economic and financial sources)) [heremafter cited as Fischel, Dividends]; on the larger structural picture, see Klem, The Modern Business Organization: Bargaining Under Constraints, 91 YALE L.J. 1521 (1982); on corporate reorganization, see Roe, Bankruptcy and Debt: A New Model for Corporate Reorganization, 83 CoLUM. L. REV. 527 (1983); on valuation, see Haynsworth, Valuation of Business Interests, 33 MERCER L. REV. 457 (1982); on bonds, see Bratton, The Economics and Jurisprudence of Convertible Bonds, 1984 WIS. L. REV. 667 [heremafter cited as Bratton, Convertibles], and Bratton, The Interpretation of Contracts Governing Corporate Debt Relationships, 5 CaRdozo I. REV. 371 (1984) [hereinafter cited as Bratton, Interpretation]. 
worlds. This educator accepts the law school's traditional dual role as an academy for legal scholarship and professional education. But he also envisages it as a "center" for "imteraction" not only among teachers and students but also among practitioners, judges, and perhaps others-bureaucrats, businesspersons, journalists, and potiticians. He inay be disquieted by the characteristics displayed by much recently published literature-it looks hike jurisprudence and speaks the language of the university's social science or humanities departments rather than that of the legal profession. He wonders how the law school can continue to be a professional center if this type of scliolarship becomes the norm. As its faculty's intellectual pursuits extend outside of the professional sphere, the nature of the professional training the school offers must cliange. Less interaction with the constituencies from outside of the university will occur. But, at least in the corporate area, this legal educator need not worry inordinately. There, no sucli chasins will open, and for a number of reasons. One is economic. The stakes in corporate law policyinaking can be high enough to proinpt professionals to make the effort to acquaint themselves with academic discourse. Another reason is pedagogic. Courses like Corporate Fimance introduce the next generation of corporate practitioners to the tenor and concerns of corporate academic discourse. Sucl interdisciplinary courses shonld continue to assist im keeping acadeinic developinents accessible to the bar. ${ }^{37}$

\section{The hamilton Alternative}

The Brudney and Chirelstein book challenges the instructor. Undertaking its full progranı requires a four-hour format, and the total concentration of everyone involved. The book lends itself to a three-liour frainework only with heavy cuts.

Hamilton's Corporation Finance offers a less daunting, more compact version of the Brudney and Chirelstein model. It covers the sante cluster of financial topics, ${ }^{38}$ but it offers a truncated presentation of a number of them, particularly preferred stock, capital structure, and dividends. The book inatches Brudney and Chirelstein's elaborateness only for inergers and other corporate coinbinations, where it includes a generous sainpling of conteniporary commentary on mergers and tender offers.

37. Of course there are many other poimts of contact. Law review students, on their way to practice, review and edit much legal academic work. Academics write in practitioner journals. Practitioners become academics; academics become practitioners.

38. That is, valuation, R. HAMILTON, supra note 5, at 1-54; senior securities, id. at 213-392; legal capital, id. at 55-129; capital structure, id. at 393-429; dividends, id. at 430-94; and mergers and other corporate combinations, $i d$. at 495-831. Hamilton departs from the Brudney and Chirelsten nodel to imclude a chapter on close corporation financial matters, id. at 130-67. 
The federal securities law topics Brudney and Chirelstein treat extensively are dispensed with. Hamilton thus affirms the Brudney and Chirelstein concept of the course, but adapts it for imstructors preferring a slow, steady, and thorough advance through course materials. A class can be conducted adagio through the entire Hamilton book in a threehour framework. Take the book andante con spirito and one can teach it in two.

Hamilton's variation on the Brudney and Chirelstein course concept reflects a number of differences in pedagogic temperament. For example, Hamilton does not attempt to replicate the overarching valuation theme. $\mathrm{He}$ is also less Socratic in his presentation. Brudney and Chirelstein often mundate the student with variegated economic, legal, and moral principles, ${ }^{39}$ biddimg her to figure it all out herself. Hamilton sometimes makes similarly traditional demands, but tends to present a more easily manageable data base when he does $\mathrm{so}^{40}$ and occasionally abandons the game altogether, choosing scholarly summaries that present the points neatly. ${ }^{41}$

Hamilton also reshapes the manner in which interrelated legal and econonric materials are presented. Brudney and Chirelstein, despite all their substantive innovations, tend to organize their materials in the time-honored manner of casebooks. "Principal cases" are followed by "notes" containing "materials" that assist analysis of the issues in the "principal cases." This format implies that the case is the primary substantive concern. But the imphication can be misleading in Brudney and Chirelstein's substantive construct, for the economic materials often prove as interestimg as the principal cases. Hamilton arranges his materials inore flexibly, implying substantive parity between legal and economic materials. ${ }^{42}$

39. Brudney and Chirelstein's presentations of valuation, discussed in the text accompanying notes 13-16 supra, and capital structure, discussed in note 42 infra, are examples. See also infra note 40.

40. Compare Hamilton on preferred stock, R. HAMILToN, supra note 5, at 213-56, capital structure, $i d$. at 393-429, and dividends, id. at 430-55, with Brudney and Chirelstein on the same subjects. BRUdNeY AND Chirelstein, Corporate FinanCE, supra note 1, at 174-244, 317-415, 416-54.

41. For example, Hamilton reties on Roe, Bankruptcy and Debt, supra note 36, to explain chapter 11 reorganization proceedings. R. Hamlton, supra note 5, at 307-16. See also Hamilton's trcatment of valuation, discussed in note 45 infra.

42. Hamilton's organizational flexibility also may stem from sensitivity to the limited attention spans of some law students. Brudney and Chirelstein's adherence to traditional casebook organization sometimes results in 50 or 100 page agglomerations of interrelated material that the student must assimilate as a single exercise. Hamilton tends to break things down. He will acquaint the student with the busimess dynamic in one exercise, and go on to the legal application of the business point in a subsequent assignment. 
Comparing the two books' treatments of valuation provides a finer sense of the choice they pose. Both start with the subject and both introduce the student to the basic economic principles. Both show that the inexact nature of the science causes difficulties when valuation disputes arise in legal contexts. The books employ very different means to these ends, however. Brudney and Chirelstein draw on the business textbook, bringing over the elementary business exercise complete with fornulas and tables. The student obtains an understanding of valuation as a component in the process of investment decisionmaking. Brudney and Chirelstein force the student to self-teach the great interdisciplinary lesson of finance ${ }^{43}$ by asking her to bring this understanding to dated legal materials. ${ }^{44}$ The exercise is painful, but the student gains in intellectual strength. Hamilton introduces valuation less as a pure busmess phenomenon than as a busimess phenomenon bearing on legal practice. His materials, taken mostly from the taxation area, clearly summarize the factors operative in the best contemporary practice of legal valuation..$^{45}$ Because all the variables are laid out in plain view, the exercise pains the student very hittle.

The different presentations create different impressions of the world. In Hamilton's world, valuation is yet another set of factors to be mastered by the legal technician. Expert witnesses provide the facts in this world. The lawyer's job is to understand this raw material and learn to mamipulate it. Brudney and Chirelstein, in contrast, do not show their students that authoritative and contemporary legal sources summarize the economic principles. They ask their students to infuse economic real-

As an example, compare the two books' treatments of capital structure. Brudney and Chirelstein offer 98 pages on this, starting with conventional business wisdom about debt-equity ratios, followed by materials presenting problems with the legal regulation of capital structure, and then modifying the whole unit with the Modigliani-Miller irrelevance hypothesis. BRUDNEY \& CHIRELSTEIN, CORPORATE FINANCE, supra note 1, at 317-415. Hamilton offers the practical busiuess view first. Next he counterbalances the economic theory. Only then does he bring on the legal material. It is all over in 37 pages. R. HAMILTON, supra note 5, at 393-429.

43. It should be noted that the 1984 supplement to the book includes the prime exemplars of the contemporary view, although not as addenda to the valuation chapter. See V. BRUDNEY \& M. Chirelstein, Cases and Materials on Corporate Finance 54, 62-63, 65-66 (Supp. 1984) (excerpting Weinberger v. UOP, Inc., 457 A.2d 701 (Del. 1983); N.Y. BuS. CoRP. LAW \& 623(h)(4) (McKinney Supp. 1983)) [hereinafter cited as BRUdNEY \& CHIRELSTEIN, SuPP. 1984].

44. See supra notes 13-16 and accompanying text.

45. Hamilton gives us quite a collection of lucid expositions of valuation, particularly the "old man and the trce" parable, R. HAMILTON supra note 5, at 1-7 (excerpt from L. Solomon, R. STEVENSON, \& D. SCHWARTZ, supra note 2 , at 83-88), and a case detailing the conflicting valuation opinious of three highly qualified experts, R. HAMILTON, supra note 5, at 23-31 (Estate of Newcoiner v. United States, 447 F. Supp. 1368 (W.D. Pa. 1978)). 
ities into older, inore rigid legal concepts. ${ }^{46}$ The perceptive student should take away an enduring skepticism about the soundness of economic assumptions underlying legal doctrine. 47

\section{FurTher COMMENTS}

\section{A. Senior Securities as Teaching Material.}

Corporate Finance introduces students to senior securities. The "law of senior securities," if such a thing may be said to exist, is an amalgam of contract, corporate, trust, and securities law. Its core is contractual. Most of the priorities and other rights that bondholders and preferred stockholders have against issuers and junior-ranking securityholders are products of investment contracts. In the case of preferred stock, state corporation law adds a regulatory overlay to this contractual core. In the case of publicly issued debt securities, heavy regulation of the contracting process comes from the state law of corporate trust and the Federal Trust Indenture Act. ${ }^{48}$ Legal issues can arise in any or all of these doctrinal arenas when disputes erupt between the semior and junior securityholders of solvent corporations.

The law of semor securities has a technical complexity that inakes it seem less rewarding from a law teacher's perspective than other corporate material. It appears to lack a compelling policy dinnension. But careful inspection of the relevant legal materials dispels this impression. Whether produced by a court, legislature, or private parties at the contract negotiating table, the law relating to semor securities does not differ in kind from other corporate law. It governs the relations of managers and securityholders and resolves their pie-shicing contests.

Both casebooks convey this point by drawing primarily on case law resolving contract disputes over the scope of the senior securityholders'

46. Hamilton creates an opportunity for critique of contemporary corporate law valuation stan. dards by including Pienıonte v. New Boston Garden Corp., 377 Mass. 719, 387 N.E.2d 1145 (1979).

R. Hamilton, supra note 5, at 33-41.

47. The business materials in Brudney \& Chirelstein's valuation chapter end with risk and re. turn. The instructor who wants to lay ont most of the economic theory at the start of the course can bring forward from the back of the book the treatnient of the Capital Asset Pricing Model (CAPM) and the efficient capital market hypothesis. See BrUdney \& CHIRELSTEIN, CoRPorate Finance, supra note 1, at 66-70, 1143-93. The materials dovetail micely: the CAPM materials take the risk and return points and work then out logically in the context of a conipetitive trading niarket. Introducing these theoretical materials early in the course also enlivens the discussion of all of the succeeding legal materials. Perceiving this, Hamilton places his treatınent of the efficient market point near the front of his book. See R. HAMILToN, supra note 5, at 185-212. He does not includc materials on the CAPM.

48. 15 U.S.C. $\S \S 77 \mathrm{aaa}-77 \mathrm{bbb}(1982)$. 
rights. ${ }^{49}$ Such cases arise when management takes action benefiting common stockholders at the expense of a class of bondholders or preferred stockholders. The governing imvestment contract fails either to mention or clearly to prohibit the conduct in question. A disadvantaged senior securityholder requests judicial intervention in the relationship, raising an issue in any one of a number of doctrinal frameworks-contract interpretation, contract avoidance, or corporate fiduciary duty. Judicial responses to these senior securityholder claims range along the entire busmess law contimuum both doctrinally and emotionally. At one end lies the hiteralistic mode of Willistoman contract law with its attendant individualistic associations. At the other end lies tlie concept of corporate fiduciary duty witl its attendant altruistic associations. There bemg no ascendant doctrinal framework, judicial responses lave free play.

Botlı casebooks display tlie entire range of judicial response. But they deploy different nuaterials to do so. Brudney and Chirelstem's second edition sliowed the full range of doctrine and judicial motivation only in its treatment of preferred stockholder riglits. On bondliolder rights it offered only a pair of cases, Aladdin Hotel v. Bloom ${ }^{50}$ and Harff v. Kerkorian, ${ }^{51}$ decided in 1953 and 1975 respectively. Botli cases reject bondliolder claims agamst opportunistic issuer conduct in strongly individualistic terins. Botli teacli the bondholders tlie great Willistonian lesson: next time, look out for yourself witl a better-drafted set of contract provisions. While similarly-minded decisions appear in their preferred stock materials, tliose materials also sliow judges who will not sanction the opportunistic conduct benefitting the common stockholders. In one instance, a judge even speaks in terms of a fiduciary duty owed by the issuer to the preferred. 52

49. A fuller picture would emerge if additional contractual materials were included. See infra text accompanying notes 79-87.

50. 200 F.2d 627 (8th Cir. 1953); see BRUdNEY \& ChIRELSTEIN, CoRPORATE FinanCE, supra note 1 , at $85-91$.

51. 324 A.2d 215 (Del. Ch. 1974), rev'd, 347 A.2d 133 (Del. 1975); see BRUDNEY \& CHIRELSTEIN, CORPORATE FINANCE, supra note 1, at 255-56.

52. At one extreme, we find Judge Frank in Guttmann v. Illinois Cent. R.R. Co., 189 F.2d 927, 930 (2d Cir.) (dismissing the preferred claim with consummate individualism: "[P]referred stockholders are not-like sailors or idiots or infants—wards of the judiciary."), cert. denied, 342 U.S. 867 (1951), excerpted in BRUdNey \& ChIRELSTEIn, CoRPorate Finance, supra note 1, at 181. The counter-balancing strain of altruisin finds only weak expression-a Delaware district judge expressed concern about the treatment accorded the preferred but felt bound to be tough under state law in Barrett v. Denver Tramway Corp., 53 F. Supp. 198 (D. Del. 1943), aff'd 146 F.2d 701 (3d Cir. 1944), and the Rhode Island Supreme Court found a fiduciary dnty owed to the bondholders but did not manage to apply it so as actually to protect thein in Bove v. Community Hotel Corp., 105 R.I. 36, 249 A.2d 89 (1969). See Brudney \& Chirelstein, Corporate Finance, supra note 1, at 212-26. 
Together, these materials impart the correct impression that an individuahistic strain dominates judicial responses to semor security holders' claims. Comparison of the materials' bond and preferred components suggests two other points. First, judicial altruism and associated protective doctrines come to the aid of securityholders in increasing intensity as their interests becoine more junior in status. This impression may be correct; at least it can be defended. ${ }^{53}$ Second, bondholders inspire no altruistic protections. As creditors, they have a wealth of self-protective devices at their disposal. In contrast, the positive law framework governing preferred stockholding inhibits the range of self-protective devices and accounts for the appearance of the altruisin of preferred stock case law. This impression may have appeared to be correct at one time. But the last two decades of case law respecting bondholder rights gives rise to a different, more complex, picture.

Hamilton's book truncates the presentation of preferred stock cases, but adds a generous sampling of these recent bond cases. ${ }^{54}$ It presents a wide-ranging collection of judicial responses to bondholder claims. The entire spectrum of emotion and doctrine appears from stern individualism and classical contract doctrine through hesitant altruism and the good-faith duties of neoclassical contract and on to aggressive impositions of cooperative spirit and corporate law fiduciary duties. ${ }^{55}$

Hamilton's bond cases teach an interesting lesson. Between their varied and complicated fact patterns and their varied judicial responses, no conventional doctrinal synthesis can be devised. Legal norins and the various policies of market regulation underlying them do not deterinine judicial intervention in semor-jumor securityholder disputes; the individualistic or altruistic disposition of the decisionmaker may be the critical factor. Individualism, while the dominant mode of judicial response, shares the scene with a strain of altruistic intervention in the bondholder's favor. Thus, the jurisprudence of high finance contracts differs

53. For a bold illustration, see Green v. Hamilton Int'l Corp., No. 76 Civ. 5433 (S.D.N.Y. July 11, 1981) (available Feb. 8, 1985 on LEXIS, Genfed library, Dist file), in which convertible bondholders are accorded fiduciary protection only where the wrong impinges on the bond's equity aspect.

54. See R. HAmilton, supra note 5, at 275-86, 336-92. In order of appearance, the cases are Sharon Steel Corp. v. Chase Manhattan Bank, N.A., 691 F.2d 1039 (2d Cir. 1982), cert. denied, 103 S. Ct. 1253 (1983), Pittsburgh Terminal Corp. v. Baltimore \& O.R.R. Co., 680 F.2d 933 (3d Cir. 1982), cert. denied, 103 S. Ct. 475 (1983), Van Gemert v. Boeing Co., 520 F.2d 1373 (2d Cir.), cert. denied, 423 U.S. 947 (1975); Broad v. Rockwell Int'l Corp., 642 F.2d 929 (5th Cir.) (en banc), cert. denied, 454 U.S. 965 (1981).

BrudNey \& ChIRELstein, SUPp. 1984, supra note 43, at 4-15, includes the Pittsburgh Terminal opinions. The Broad fact situation is summarized as a problem. Id. at 16.

55. For detailed discussions, see Bratton, Convertibles, supra note 36, and Bratton, Interpretation, supra note 36 . 
less from that of other contractual and corporate contexts than many Wall Street individualists would like to think. ${ }^{56}$

\section{B. Academic Commentary as Teaching Material.}

If we were to set out to collect the best exeinplars of the corporate law discourse of three decades ago we probably would settle on a handful of judicial opinions. The Swan and Clark opinions in Pearlman v. Feld$m{ }^{57}$ coine especially to mind. ${ }^{58}$ One wonders whether any of the era's academic work on corporate law also would be included. The academics who produced it tended to share the jurisprudential and empirical assuinptions underlying the judicial opinions on which they commented and reflected. They offered no explanation of the place of corporate law in the wider world or the place of the wider world in corporate law. This left them without the force of ideas to compensate for their lack of power to tell people what to do. As a result, their commentary held only a secondary place on the law hibrary shelf. ${ }^{59}$

Less and less contemporary academic commentary shares the jurisprudential and einpirical assumptions of judicial opinions. Much of it reaches outside of the traditional body of corporate law in search of expanded empirical knowledge and normative inspiration. While not "real law" like cases and statutes, it can have the independent force of insight. Surely the inost coinpelling discourse in this decade's legal financial hiterature is that between scholars of the Chicago school-Professors Frank Easterbrook and Daniel Fischel most notably-and their opponentsamong whoin Professor Victor Brudney figures prominently.60 One doubts whether any of today's judicial opinions will achieve similar

56. Enhanced understanding of the dynamic of decisionmaking operative in the cases respecting bonds and preferred calls for a relational rather than a doctrinal inquiry. For relational inquiries respecting senior securities, see Bratton, Convertibles, supra note 36, at 672-719; Brudney, Standards of Fairness and the Limits of Preferred Stock Modifications, 26 RUTGERS L. REV. 445, 448-50 (1973); Carlson, $A$ Theory of Contractual Debt and Lien Subordination, 38 VAND. L. REV. (forthcoming 1985). On relational scholarship in general, sec MacNeil, Relational Contract: What We Do and Do Not Know, 1985 WIS. L. REV. (forthcoining).

57. 219 F.2d 173 (2d Cir. 1955) (Clark, C.J.); id. at 178-80 (Swan, J., dissenting).

58. The Newport Steel 10b-5 case, Birnbauun v. Newport Steel Corp., 193 F.2d 461 (2d Cir. 1952), might also be included. The other leading corporate opinions of the 1950's tend to come from state courts, federal rights of action not yet having proliferated widely. See, e.g., Campbell v. Loew's, Inc., 36 Del. Ch. 563, 134 A.2d 852 (1957); In re Auer v. Dressel, 306 N.Y. 427, 118 N.E.2d 590 (1954).

59. Berle is the exception. See A. Berle, Power Without Property 1-26 (1959).

60. Compare Brudney, Equal Treatment, supra note 25, with Easterbrook \& Fischel, Corporate Control Transactions, 91 YALE L.J. 698 (1982); Brudney, Dividends, supra note 25, with Fischel, Dividends, supra note 36. 
status. ${ }^{61}$

This shift in the balance of influence on the law library's shelves has implications for advanced corporate law pedagogy. If the most interesting ideas on the subject cannot be culled from cases and statutes, and if finding these ideas requires reference to scholarly materials, it follows that the scliolarly inaterials sliould be integrated into the syllabus. As the curricular context becomes more advanced, this case gets stronger. By the time students take Corporate Finance they know low to read cases and statutes and talk policy; expanding the acadeimic scope of the courses does not impair their professional training. Accomplishing an integrated approach will improve professional coliesion by cultivating an appreciation for advanced scholarship in the next generation of practitioners.

None of this should come as news to Brudney and Chirelstein, whose book mcludes mucl scliolarship. ${ }^{62}$ Hamilton includes even more. Indeed, it is in the scliolarly component that we finally detect an overarching theine in Hamilton's book. Unhike Brudney and Cliirelstein, who direct attention to economic and legal actors making decisions affecting value, Hamilton directs attention to economic and legal scholars inaking assertions regarding the regulation of economic actors. Hamilton shows that the Chicago school's critique bears on every governmental intervention in financial matters. The student, whatever his or her judgment regarding the critique's ultiunate merits, learns that the Clicago Scliool camiot be ignored in any serious discourse on corporate law, at least at present.

Hamilton develops the theme as follows: he starts early in the book witl an exposition of the efficient markets hypotlesis in its various versions. Some material highlights the claim that a body of empirical research substantiates the theory; 63 other excerpts present empirical critiques of the liypotliesis. ${ }^{64}$ Hamilton keeps the lyypothesis, and its etlical implications, in front of the student working through the cases on publicly traded bonds and preferred stock. ${ }^{65}$

61. Putting this another way, academics in the corporate area used to worry about what judges thought; now they worry about what other academics think.

62. For a summary, see Brudnex \& Chirelstein, Corporate FinanCE, supra note 1, at xix-xxii.

63. R. HAMILTON, supra note 5, at 185-97.

64. Id. at 199-207. The principal source in favor of the hypothesis is Note, The Efficient Capital Market Hypothesis, Economic Theory and the Regulation of the Securities Industry, 29 STAN. L. REV. 1031 (1977); against the hypothesis is Lowenstein, Pruning Deadwood in Hostile Takeovers: $A$ Proposal for Legislation, 83 ColuM. L. REv. 249 (1983).

65. R. Hamilton, supra note 5, at 229, 256 n.3, 328. 
Predictably, the Chicago school's profile looms larger when the book reaches the subjects it has taken up most aggressively-transfers of control and corporate combinations. The school's critique rests on two basic assertions about the financial world: the market for corporate control creates wealth by transferring assets to their highest valuing users; and, changes in corporate control should be explained as efforts by rational profit maximizers to reduce agency costs. Hanilton shows Professor Fischel applying these assertions to approve the conduct of the acquiring corporation in the freeze-out merger, ${ }^{66}$ of management in going-private transactions, ${ }^{67}$ of controlling shareholders in sales ${ }^{68}$ and other dispositions ${ }^{69}$ of control, and, of course, of offerors in tender offers. ${ }^{70}$ Hamilton includes contrasting scholarship, most importantly that of Professor Lowenstein, only on the latter point. ${ }^{71}$

This collection of material gives a working introduction to contemporary corporate law academic discourse. It should advance a number of other valuable pedagogic goals as well. The materials selected emphasize the key role empirical studies play in the debate. The student learns that justifiable market regulation must be based on understanding the nature of the market's operations and that the requisite level of understanding requires research. The student also is shown that empirical economic studies do exist. One hopes the student takes away both scruples against the lawyer's practice of transforming personal einpirical impressions into assertions of scientific truth, and skepticism regarding broad policy arguments based on narrow empirical studies.

Hamilton's presentation of the scholarship has an unfortunate onesidedness, however. Everything is Easterbrook and Fischel on the attack, wielding microeconomics agamst the old fairness imtuitions. One

66. Id. at 584-86 (excerpting Fischel, The "Race to the Bottom" Revisited: Reflections on Recent Developments in Delaware's Corporation Law, 76 Nw. U.L. REv. 913 (1982)).

67. R. Hamilton, supra note 5, at 611-13 (excerpting Fischel, supra note 66).

68. Id. at 634-37, 646-47 (excerpting Easterbrook \& Fischel, Corporate Control, supra note 60).

69. Id. at 656-57 (excerpting Easterbrook \& Fischel, Corporate Control, supra note 60).

70. R. Hamilton, supra note 5, at 694-99, $793-95$ (excerpting Easterbrook \& Fischel, Takeover Bids, Defensive Tactics, and Shareholder's Welfare, 36 Bus. LAw 1733 (1981)). We also hear from other inembers of the Chicago school and receive a taste of its internal discussions on the precise legal blueprint necessary for optimal operation of the market for corporate control. See $\mathbf{R}$. HaMiLTON, supra note 5, at 795-99 (excerpting Gilson, A Structural Approach to Corporations: The Case Against Defensive Tactics in Tender Offers, 33 STAN. L. REV. 819, 844-46 (1981), and Bebchuk, The Case for Facilitating Competing Tender Offers, 95 HaRv. L. REv. 1028, 1054-56 (1982)).

71. Hamiton, supra note 5, at 703-07 (excerpting Lowenstein, Pruning Deadwood in Hostile Takeovers: A Proposal for Legislation, 83 CoLuM. L. REV. 249 (1983) (challenging the conclusions Easterbrook and Fischel draw from empirical research on the operation of the market for corporate control and offering a broader picture of the motivations driving that market). Similar points made in SEC ADVISORY COMMITTEE ON TENDER OFFERS, REPORT OF RECOMMENDATION (1983) are included by Hamilton. See R. HAMilton, supra note 5, at 707-13. 
gets the impression that most voices on the other side have lapsed into stunned silence, although nothing of the sort has occurred. The book's picture of the contemporary debate would have had greater verisimilitude and depth had Hamilton brought others-Brudney, for exampleto assist Lowenstein im the defensive role. ${ }^{72}$

Of course, canny pedagogy may lie behind Hamilton's one-sidedness. The book's silences give the imstructor the privilege of building the response to the Chicago school's assertions in class. This approach leaves the instructor at center stage with the materials providing a basis for hively debate. The book puts on the table the Chicago school's claim to possess scientific theory that determines correct dispositions of corporate law issues. The case against this claim can be developed easily enough through the usual combination of Socratic questioning, manipulation of student commentary, and occasional lecture. General discussion of the appropriate place of the Chicago school's insights in corporate jurisprudence should follow.

A tittle well-placed assistance in the casebook could propel this discussion to a higher level of sophistication. ${ }^{73}$ For example, Hamilton's presentation of the efficient markets discussion closes with Easterbrook and Jarrell stating that no market is absolutely efficient. ${ }^{74}$ The Chicago school retreats from its black-and-white vision with this concession. As these shades of gray start to emerge in its picture of market operations, the school's normative challenge against market regulation loses intensity. ${ }^{75}$ Market efficiency devolves into a "factor" in a conventional policy dispute in which fairness and efficiency weigh against one another. A new question arises: if everyone agrees that securities markets tend to be very efficient, disputing ouly small matters of the degree of efficiency, and if when a market is "very" as opposed to "perfectly" efficient its effi-

72. For example, the Easterbrook \& Fischel commentary on going-private sales and other dispositions of control, see supra notes 56-57 and accompanying text, could be counterbalanced with excerpts from Brudney, Equal Treatment, supra note 25, at 1091-98, 1122-26.

Coffee, Regulating the Market for Corporate Control: A Critical Assessment of the Tender Offer's Role in Corporate Governance, 84 CoLum. L. REV. 1145 (1984), was published after the Hamilton book. It might be utilized to enhance the tender offer discussion in the next edition.

73. Hamilton takes a small step in this direction with an excerpt from Kitch, The Intellectual Foundations of "Law and Economics," 33 J. LEGAL EDUc. 184, 194-95 (1983) (noting a few phenomena not yet worked into the fabric of efficient market theory), excerpted in R. HAMILTON, supra . note 5 , at 197-98.

74. R. HAMILTON, supra note 5 , at 211 .

75. Recent literature develops both the more complex picture of market operations and its normative imphications. See Gilson \& Kraakman, supra note 31 . Responding to this article, Professor Levmore questions whether the efficient market hypothesis should be accorded any normative significance at all. Levmore, Efficient Markets and Puzzling Intermediaries, 70 VA. L. REv. 645, 656-57 (1984). As already noted, see supra note 73, the Hamilton book makes a bow in the direction of this more sophisticated strain of scholarship. 
ciency leads to no normative imperative, then exactly what hes behind the Chicago school's critique? We see in the root and branch attack on regulation not the product of scientific inquiry but the product of a particular world view. What are its constituent eleinents and do the world views underlying opposing corporate law scholarship differ in any inaterial respect?

Corporate law hiterature offers little assistance on these questions. ${ }^{76}$ It tends to concern itself only with finding and defending "correct" answers to discrete regulatory questions. But discussion of the appropriate normative place of the efficiency primciple and of the individualist political inotivations of its inost fervent proponents does exist in other fields. ${ }^{77}$ Of course such commentary does not directly address corporate law issues. But its important bearing on the ineaning of the Chicago school's corporate critique requires us to be flexible regarding subject inatter barriers. Once we go so far as to introduce our students to the Chicago school and its opponents we might as well take the sinall further step of introducing thein simultaneously to the deeper critique of the ineaning of such legal scholarship.

\section{Contract Relationships as Teaching Material.}

The almost exclusive einphasis on cases, statutes, and other "real law" in legal education distorts its presentation of business relationships. The more sophisticated these relationships become, the inore contracts displace "real law" as the primary source of governing rules. Teaching only the "real law" obscures significant components of the overall relationship.

Let us consider two subjects as to which the corporate law curriculum omits significant contractual components: close corporation planning and the jurisprudence of information. The Corporations course teaches close corporation planning by focusing on cases and statutes, even though the shareliolders' agreement is the relational mainspring. The casebooks deal with the contractual coinponent by describing provisions likely to be found in these agreements, rather than by including a

76. Romano, Metapolitics and Corporate Law Reform, 36 STAN. L. REV. 923 (1984), is a significant exception. This work elaborates a typology of the different conceptions of democratic organization that underlie corporate law scholarship. Professor Romano's discussion of the conceptual schism between welfare state pluralists and minimal state pluralists, $i d$. at $942-45$, could be drawn on to impart an understanding of the world views that motivate contemporary academic discourse on corporate law.

77. See the discussions of the law and economics movement in Symposium on Efficiency as a Legal Concern, 8 Hofstra. L. Rev. 485 (1980). See also Frug, supra note 29, at 1355-77, offering the views of an adherent of Critical Legal Studies on "market/pluralist" theories for control of corporate management. 
contract specimen or parts thereof. ${ }^{78}$ The books, in effect, bid the student to study the contractual component only insofar as it bears on the "real law." As a result, the student takes away a thorough understanding of the law that enables, validates, and enforces contracts among shareholders, but gains only a hazy notion of the economic interests at stake and the bargaining dynamic and legal devices that bring about their adjustment.

The corporate curriculum teaches information disclosures by sellers and issuers of securities as a part of the field regulated by the federal securities laws. Private contract structures serving the same regulatory function-the representations and warranties of the large financing-are not customarily employed in teaching. ${ }^{79}$ Nor, despite extensive discussion of materiahity in the federal law context, does the curriculum offer examples of these contracts to demonstrate concretely what real parties think is important. As a result, the student takes away a stilted view of the jurisprudence of information. She sees buyer protection as almost entirely a matter of paternalistic federal intervention, and does not see the complementary regime of two-fisted bargaining over information disclosure that completes the picture.

Both Corporate Finance books follow the traditional "real law" approach, even as they teach relationships subject to substantial contractual goveruance-the relationships of issuers and holders of debt securities, of issuers and preferred stockholders, of partners to mergers, and of parties to asset sale agreements and stock purchase agreements. The books recognize the existence of contracts governing these relationships, but supply only cursory descriptions of their contents. No specimens are included. Student efforts are limited to the "real law" governing these relationships. Although resulting gaps and points of confusion remain relatively innocuous in the case of mergers, they become more substantial with asset sales, preferred stock, and debt.

78. See, e.g., W. CARY \& M. EISENBERG, supra note 9, at 366-517; A. CoNARD, R. KNAUSs, \& S. SiEgel, ENTERPRISE ORganization 770-813 (2d ed. 1977); R. Hamilton, CASES AND Mater-

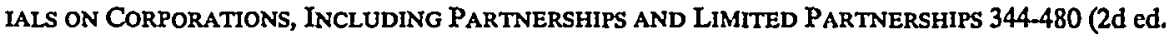
1981); H. Henn, CASes and Materials on the Laws of Corporations $601-709$ (1974) (containing a sample deadlock provision at 690-91); A. FREY, J. CHOPER, N. LEECH, \& C. MORRIS, Cases and Materials on CoRporations 519-652 (2d ed. 1977); L. Solomon, R. STEvenson, \& D. SchWARTZ, supra note 2, at 302-77; D. VAGTS, BASIC CORPORATION LAW: MATERIALS CASES - TEXT 776-822 (2d ed. 1979).

79. Jennings and Marsh, however, do provide a documentary supplement to their Securities Regulation casebook for those wanting documentary exemplars when teaching registration under the Securities Act of 1933. See R. Jennings \& H. Marsh, Selected Statutes, Rules and Forms UNDER THE FEDERAL SECURITIES LAW (1984). For a transaction-costs explanation of the standard set of representations and warranties, see Gilson, supra note 27 at 269-73, 276-80. 
For a closer look at the problem, consider the books' treatments of long-term debt relationships. Students of both books study the "real law"- the Trust Indenture Act as it restricts on the debt contracting process, the Bankruptcy Act as it cancels and reconstructs debt contracts, and judicial decisions that interpret debt contracts. Both books prepare the students for this work by describing the contents of debt contracts. But the preparation proves inadequate. Not having studied the debt contracts theinselves, inost of the students will not have achieved a concrete understanding of the contracts' structure and risk-allocating function. Without this understanding, the "real law" material comes across as very technical and somewhat mysterious. ${ }^{80}$

It need not be left to practice to fill in coinplete pictures of these relationships. Examples of bonds and notes, business covenants, issuer prepayment provisions, conversion provisions, preferred stock priority provisions, representations and warranties of issuers, merger partners, and stock and asset sellers, and other financial contracting devices could

80. Brudney \& Chirelstein excerpt Dewing's descriptions of the sorts of provisions customarily included in debt contracts. See Brudney \& Chirelstein, Corporate Finance, supra note 1, at 84-85 (quoting 1 A. Dewing, The Financial Policy of CoRporations 173-74 (5th ed. 1953)). Hamilton makes a similar move by including the table of contents from the Model Simplified Indenture. See R. Hamilton, supra note 5, at 272-74 (quoting Model Simplified Indenture, 38 Bus. LAW 741, 745-47 (1983)).

Contract forms are important starting points in a corporate law pedagogy centered on contractual relatiouships. Once he has mastered the structure of the relationship, the student can be taken on to the law that regulates the structure and the economic theory that explains the structure. This pedagogic assertion rests on an assumption similar to the assumption that studying primary source legal inaterial is valuable. Teaching contract relations without teaching the contracts has the same limitations as teaching a Contracts course out of a hornbook.

Professor Gilson, also arguing for the teaching of contractual relationships in the corporate law curricnlum, would leave out the contract forms and look only to economic theory for relational teaching materials. See Gilson, supra note 27, at 303-06. In his view, contract forms, like other practice-oriented subject inatter, cannot be adapted to the law school environment:

Among a number of problems . . . is that most legal academics are not really competent to teach these skills; the career patterns of teachers at leading law schools typieally do not refiect sufficient time in practice to have themselves perfected the skills that this approach to business law education would require.... Law firms and real practitioners, through soine form of apprenticeship, are likely to do a far better job than any law school for a number of reasons.

Id. at 304 (footnotes omitted). While these comments are persuasive with respect to teaching practitioner arts like negotiation and drafting, they are not persuasive with respect to teaching contract forms. Notwithstanding the understandable desire of practitioners to mystify their deals and dealmaking, their contract forms, or exemplars of them taken from real transactions, can be employed by legal academics teaching contractual relationships. An academic with only limited exposure to practice can explicate a contractual text without command of the practical skills necessary to create such documents in real world situations.

If, in redireeting corporate law acadeuric endeavors to the combined study of theory and practice in busmess relatiouships, we underplay legal practice too much, we delegitimate ourselves somewhat. Without a practieal legal component, the work might as well be done in the university's economics department. 
be integrated into a Corporate Finance casebook. Such inaterials would show economic interests being translated into complex legislation by those directly affected. Thus, exposure to thein would advance students' understanding of the interworkings of law and economic forces. Exposure to thein also would give students a concrete contextual basis upon which to study and evaluate the real law of finance.

It is fair to argue that students find this sort of inaterial boring and frustrating. But it is fair to reply that curricular staples like federal tax regulations and the Rule 140 series under the Securities Act of 1933 hardly differ in this regard, and exeinplars of coinplex finance contracts considerably better drafted than such legislation are not hard to find. It also is fair to argue that coinplex contract inaterials impose inore intense technical demands than does inuch of the "real law" of corporations. And it is fair to reply that the meaning and imier mechanics of complex contract provisions can be inade quite accessible with the inclusion of problein sets to guide the student, and we should be seeking out technically demanding inaterials for advanced corporate courses in any event. ${ }^{81}$

Unexpected support for a contractual adjustment of the Corporate Finance course can be found in soine recent corporate law scholarship. This work, following the social sciences, seeks to describe and explain business relationships rather than to summarize and sharpen or rewrite the legal doctrine governing thein. These legal scholars ${ }^{82}$ in effect have joined with a group of economists ${ }^{83}$ in a search for explanations of the interconnected legal constructs in which economic activities occur in and around the firm. The significance accorded to private contracting varies depending on the particular work and the philosophical perspectives underlying it. When the work coines froin Chicago school economists, an underlying anti-positivisin ${ }^{84}$ brings contract to the fore, normatively and

81. Those in search of antidotes to "third-year malaise" should consider introducing students to materials that bear on their futures and simultaneously challenge their legal reading and comprehension skills. The exercise calls for fortitude, but has its rewards if undertaken with conviction.

82. See, e.g., Easterbrook \& Fischel, Voting in Corporate Law, 26 J.L. \& EcoN. 395 (1983); Klein, supra note 36; Levmore, Monitors and Freeriders in Commercial and Corporate Settings, 92 YALE L.J. 49 (1982).

83. There are different schools of thought here. For a look at some of them, see Jelisen \& Meckling, Theory of the Firm: Managerial Behavior, Agency Costs and Ownership Structure, $3 \mathrm{~J}$. FIN. Econ. 305 (1976); Fama, Agency Problems and the Theory of the Firm, 88 J. PoL. EcoN. 288 (1980); Fama \& Jensen, Separation of Ownership and Control, 26 J.L. \& EcoN. 301 (1983), and Scott, Corporation Law and the American Law Institute Corporate Governance Project, 35 STAN. L. REV. 927 (1983) (demonstrating the influence this work has among legal scholars). For the other school of thought, see Williamson, Corporate Governance, 93 YALE L.J. 1197 (1984); and Williamson, The Modem Corporation: Origins, Evolution, Attributes, 19 J. EcoN. LrT. 1537 (1981).

84. Professor Arthur Jacobson describes anti-positivists as follows:

These critics of modern positivism abhor a system in which the sole effective source of order is the state apparatus. Society, they reflect, is abundant with spontaneous arrange- 
doctrinally. Here the firm is conceived as a "bundle of contracts,"85 and under the efficiency principle, private contractual concepts are employed to justify real law. To these scholars, corporate law is justified to the extent that it saves contracting costs for private parties. Other work brings contract into an overarching and more collectivist vision of human relationships. The so-called Relationahists look past the conventional divisions of legal subject matter to view corporate law as one of many branches of a law of relational contracts. They are inore eclectic in finding principles to justify real law. ${ }^{86}$ Whichever perspective is employed, the traditional "real law" subject matter limitations of the legal academy tend to be disregarded.

This work admits contracting patterns to parity with statutes and judicial gap-filling rules as meaningful sources of busimess law. It invites a unitary study of the firm's financial structure which considers all regulations playing a significant role in the firm's structure and governanceinvestment contracts and merger and asset sale contracts as well as state and federal corporation laws and judicial opinions. The different sources of authority-contractual assent in one case, and sovereigu power in the other-although relevant, should not circumscribe the inquiry. ${ }^{87}$

If we turn these perspectives to law teaching, we begin to see that the traditional "real law" bias need not inevitably control Corporate Finance pedagogy. The bias no longer controls corporate law scholarship. And contracting patterns have an obvious practical bearing on the study of the lawyer's role in corporate finance.

\section{CONCLUSION}

The challenge to the editor of the next Corporate Finance casebook is clear. The bounds on the present curricular concept can be relaxed to

\footnotetext{
ments among persons, formed without the state's aid and enabling authority. Persons are the source of energy and order in the economy and in cultural life . . . .

Law, to these anti-positivists, is neither legislation nor enforcement. It is the ratification or restoration of spontaneous arrangements .... It forces, or thrcatens to force, only what persons agrce shall be forced. The principles of law, therefore, are coterminous with the principles of contract.
}

Jacobson, The Private Use of Public Authority: Sovereignty and Associations in the Common Law, 29 Buffalo L. REV. 599, 612-13 (1980).

85. For a brief summary of this "modern theory of the firm," see Kraakman, Corporate Liability Strategies and the Costs of Legal Controls, 93 YALE L.J. 857, 862-64 (1984). "The doctrinal case for the bundle of contracts theory is set out in Hessen, $A$ New Concept of Corporations: A Contractual and Private Property Model, 30 Hastings L.J. 1327, 1334-36 (1979). For a critique of Hessen's position, see Frug, supra note 29, at 1305-07. For the doctrinal argument opposing the bundle of contracts theory, see Jacobson, supra note 84, at 612-15.

86. See generally MacNeil, supra note 56.

87. Ultimately, of eourse, sovereign power enters into contractual relations as a source of enforcement power. See generally Jacobson, supra note 81 . 
admit both more theory and more practice. There is room to include more theoretical discussion, political and economic. A double contractual dimension can be added to the course. Adding contract exemplars can draw the course closer to the practical world. Adding exeinplars of theoretical thinking on the contractual structure of the firm can introduce the student to a further area of academic concern. Such innovations should benefit all of the course's varied constituencies. 